\title{
Spatio-temporal variability of summer monsoon rainfall over Orissa in relation to low pressure systems
}

\author{
M Mohapatra ${ }^{1}$ and U C Mohantr ${ }^{2, *}$ \\ ${ }^{1}$ India Meteorological Department, Guwahati 781 015, Assam, India. \\ ${ }^{2}$ Centre for Atmospheric Sciences, Indian Institute of Technology, Delhi, New Delhi 110 016, India. \\ *e-mail: mohanty@cas.iitd.ernet.in
}

The summer monsoon rainfall over Orissa occurs mostly due to low pressure systems (LPS) developing over the Bay of Bengal and moving along the monsoon trough. A study is hence undertaken to find out characteristic features of the relationship between LPS over different regions and rainfall over Orissa during the summer monsoon season (June-September). For this purpose, rainfall and rainy days over 31 selected stations in Orissa and LPS days over Orissa and adjoining land and sea regions during different monsoon months and the season as a whole over a period of 20 years (1980-1999) are analysed. The principal objective of this study is to find out the role of LPS on spatial and temporal variability of summer monsoon rainfall over Orissa.

The rainfall has been significantly less than normal over most parts of Orissa except the eastern side of Eastern Ghats during July and hence during the season as a whole due to a significantly less number of LPS days over northwest Bay in July over the period of 1980-1999. The seasonal rainfall shows higher interannual variation (increase in coefficient of variation by about $5 \%$ ) during 1980-1999 than that during 1901-1990 over most parts of Orissa except northeast Orissa. Most parts of Orissa, especially the region extending from central part of coastal Orissa to western Orissa (central zone) and western side of the Eastern Ghats get more seasonal monsoon rainfall with the development and persistence of LPS over northwest Bay and their subsequent movement and persistence over Orissa. The north Orissa adjoining central zone also gets more seasonal rainfall with development and persistence of LPS over northwest Bay. While the seasonal rainfall over the western side of the Eastern Ghats is adversely affected due to increase in LPS days over west central Bay, Jharkhand and Bangladesh, that over the eastern side of the Eastern Ghats is adversely affected due to increase in LPS days over all the regions to the north of Orissa. There are significant decreasing trends in rainfall and number of rainy days over some parts of southwest Orissa during June and decreasing trends in rainy days over some parts of north interior Orissa and central part of coastal Orissa during July over the period of 1980-1999.

\section{Introduction}

The low pressure systems (LPS) including low, depression and cyclonic storm either form over the Indian subcontinent, the Bay of Bengal and Arabian Sea or develop from the remnants of depressions/storms over Pacific Ocean and south China Sea which move westward into the Bay of Bengal during the summer monsoon season.
A large majority of these LPS form over the Bay of Bengal and adjoining areas north of $15^{\circ} \mathrm{N}$ (Jadhav 2002) and move westwards along the monsoon trough. The detailed definition of LPS including low, depression, deep depression and cyclonic storm as per criteria of India Meteorological Department (IMD) has been discussed by Mooley and Shukla (1989). There are many studies including Pisharoty and Asnani (1957); Mooley

Keywords. Rainfall variability; monsoon; Orissa.

J. Earth Syst. Sci. 115, No. 2, April 2006, pp. 203-218

(C) Printed in India. 
(1973); Dhar and Mhaiskar (1973); Joseph (1981); Rajamani and Rao (1981) and Dhar et al (1981) on the influence of cyclonic storms and depressions on the performance of monsoon rainfall over India. The southwest sector of a monsoon depression gets more rainfall due to maximum low level convergence and vertical motion (Rajamani and Rao 1981). Dhar et al (1981) have noted a significant relationship of tropical disturbances (depression and cyclonic storms) only with monthly rainfall and not with seasonal rainfall over India. Sikka (1980) has found that the frequency of monsoon lows and low days show notable difference in large excess and deficient monsoon rainfall years over India. Mooley and Shukla (1989) have studied characteristics of LPS over the Indian region $\left(5^{\circ} \mathrm{N}\right.$ to $35^{\circ} \mathrm{N}$ and $60^{\circ} \mathrm{E}$ to $100^{\circ} \mathrm{E}$ ) based on data of 1888-1983 and found that the frequency of LPS has no relation with Indian summer monsoon rainfall (ISMR), rather a good positive correlation exists between the total number of days of LPS and ISMR. According to Mooley and Shukla (1989), the rainfall over central India, which includes Orissa, is significantly and directly correlated with the frequency of LPS days over the Indian region.

Orissa state, a meteorological sub-division of India, receives about $116.7 \mathrm{~cm}$ of rainfall during the southwest monsoon season (June-September) and it is about $80 \%$ of the annual rainfall over Orissa (Parthasarathy et al 1995). It lies on the east coast of India, adjacent to north Bay of Bengal and close to the south of the eastern end of monsoon trough in the Indian region (figure 1a). Various studies including Raghavan (1973); Saha and Saha (1981) and Pathan (1993) indicate that the location of maximum rainfall roughly coincides with the position of the monsoon trough axis at $700 \mathrm{hPa}$, which roughly extends along $22^{\circ} \mathrm{N}$ across north Orissa from west to east. Also a number of LPS develop over north Bay of Bengal and move west-northwestwards along the monsoon trough. The physiographical regions of Orissa are shown in figure 1(b). Due to the orographic interaction of Eastern Ghats, the western side of Eastern Ghats becomes windward region with the basic monsoon flow as westerly in association with the synoptic disturbance over north Bay and hence gets more intense rainfall. When the disturbance lies southward, e.g., over west central Bay, the basic monsoon flow becomes easterly over Orissa and hence the western side of Eastern Ghats becomes lee side and gets less intense rainfall. Hence, the rainfall over Orissa is predominantly determined by the interaction of basic monsoon flow with the orography in Orissa due to Eastern Ghats and other mountain ranges and synoptic disturbances like LPS developing over the Bay of Bengal and moving along the monsoon trough. Considering monthly monsoon rainfall over different meteorological sub-divisions of India and LPS days over different $5^{\circ}$ latitude $\times 5^{\circ}$ longitude grids over the Indian region during 1891-1990, Jadhav (2002) has found that the rainfall over Orissa significantly increases with increase in LPS days over the grids of (i) $20^{\circ}-25^{\circ} \mathrm{N}, 80^{\circ}-85^{\circ} \mathrm{E}$ and (ii) $20^{\circ}-25^{\circ} \mathrm{N}, 85^{\circ}-90^{\circ} \mathrm{E}$ during July and August. The grid (i) covers the northern part of Chattisgarh and adjoining areas of Orissa, Jharkhand, Bihar and east Uttar Pradesh. The grid (ii) covers the northern part of northwest Bay, adjoining northeast Orissa, Gangetic West Bengal and adjoining areas of Jharkhand and Bihar. The rainfall over Orissa significantly increases with increase in LPS days over grid (ii) during June. The rainfall over Orissa significantly increases with increase in LPS days over some parts of northwest Bay and adjoining west central Bay $\left(15^{\circ}-20^{\circ} \mathrm{N}, 85^{\circ}-90^{\circ} \mathrm{E}\right)$ and over the land region covered by $\left(20^{\circ}-25^{\circ} \mathrm{N}\right.$, $\left.75^{\circ}-80^{\circ} \mathrm{E}\right)$ and $\left(25^{\circ}-30^{\circ} \mathrm{N}, 70^{\circ}-80^{\circ} \mathrm{E}\right)$ during September. According to (Mohapatra and Mohanty 2004), the rainfall over Orissa as a whole significantly increases with increase in LPS days over Gangetic West Bengal, Orissa and northwest Bay during June. During July and August, the rainfall over Orissa significantly increases with increase in LPS days over Orissa. During September, the rainfall over Orissa increases significantly with increase in LPS days over northwest Bay and decrease in LPS days over northeast Bay. During the season, the rainfall over Orissa increases significantly with increase in LPS days over northwest Bay and Orissa.

All the above studies indicate the impact of LPS on summer monsoon rainfall over Orissa as a whole. As there is varied physiography in Orissa, it is felt essential to find out the spatio-temporal variability of summer monsoon rainfall and rainy days ( 24 hours rainfall $\geq 2.5 \mathrm{~mm}$ ) over Orissa in relation to LPS. Hence, in this study, the significant relationships of monsoon rainfall and rainy days over Orissa with the number of LPS days over Orissa and neighbouring land and sea regions are brought out and analysed based on data of 31 uniformly distributed stations in Orissa during 1980-1999. The principal objective of this study is to understand the contribution of LPS to the spatio-temporal variability of monsoon rainfall over Orissa. This study is expected to help in further analysis and development of appropriate models for prediction of rainfall and rainy days over Orissa, in particular for short range prediction of monsoon rainfall over Orissa based on characteristics of LPS. 

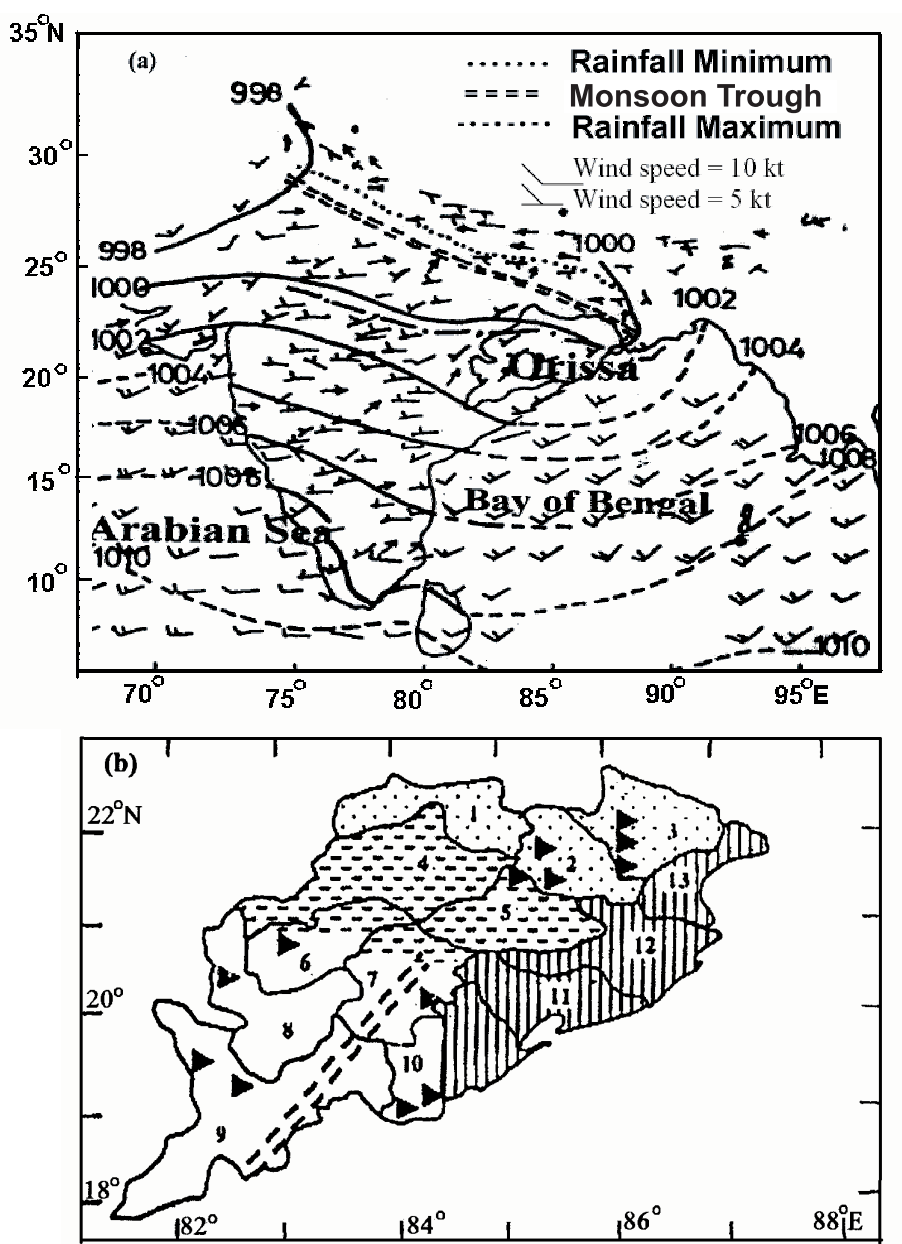

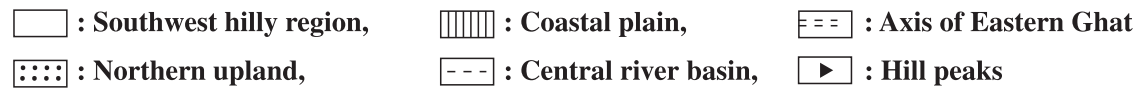

1. Sundergarh(SNG) 2. Keonjhar(KNJ) 3. Mayurbhanj(MBJ) 4. Sambalpur(SBP)

5. Dhenkanal(DNK) 6. Bolangir(BNG) 7. Phulbani(PLB) 8. Kalahandi(KLH) 9. Koraput(KRP)

$\begin{array}{lll}\text { 10. Ganjam(GNJ) 11. Puri(PRI) } & \text { 12. Cuttack(CTK) 13. Balasore(BLS) }\end{array}$

Figure 1. (a) Mean sea level isobaric pattern (in $\mathrm{hPa}$ ) and mean wind (in knots) at $0.9 \mathrm{~km}$, plotted according to WMO code over the Indian region and (b) physiography of Orissa.

\section{Data and methodology}

The characteristic features of spatial and temporal variability of summer monsoon rainfall over Orissa are analysed based on the daily rainfall recorded at 0830 IST over 31 uniformly distributed rain gauge stations in Orissa during monsoon season (JuneSeptember) for the period of 20 years (1980-1999). The rainfall data are collected from IMD. The rain gauge stations selected for the study are shown in figure 2(a). The data are quality checked and missing data, though rare, are filled up by considering the average rainfall recorded over surrounding stations. The time series of monthly and seasonal rainfall over different selected stations in Orissa are prepared from the daily rainfall. A day with 24 hours rainfall of $2.5 \mathrm{~mm}$ or more is called as a rainy day as per the criteria of IMD. The number of rainy days during different monsoon months and the season as a whole are found out and the time series of monthly and seasonal number of rainy days over different selected stations in Orissa are prepared.

The data on LPS such as their intensity, regions of occurrence and movement during summer monsoon season are collected from different weather reports published by IMD for the period of 19801999. The time series of number of LPS days over different regions are prepared for different monsoon months and for the season as a whole. The LPS days over west central (WC) Bay off north coastal Andhra Pradesh (NCAP), northwest (NW) Bay, northeast (NE) Bay, Orissa (ORS), Gangetic West Bengal (GWB), Bangladesh (BDS), Jharkhand (JKD) and east Madhya Pradesh and Chattishgarh (EMPC) are considered in the analysis (figure 2b), as LPS over these regions mostly cause rainfall 


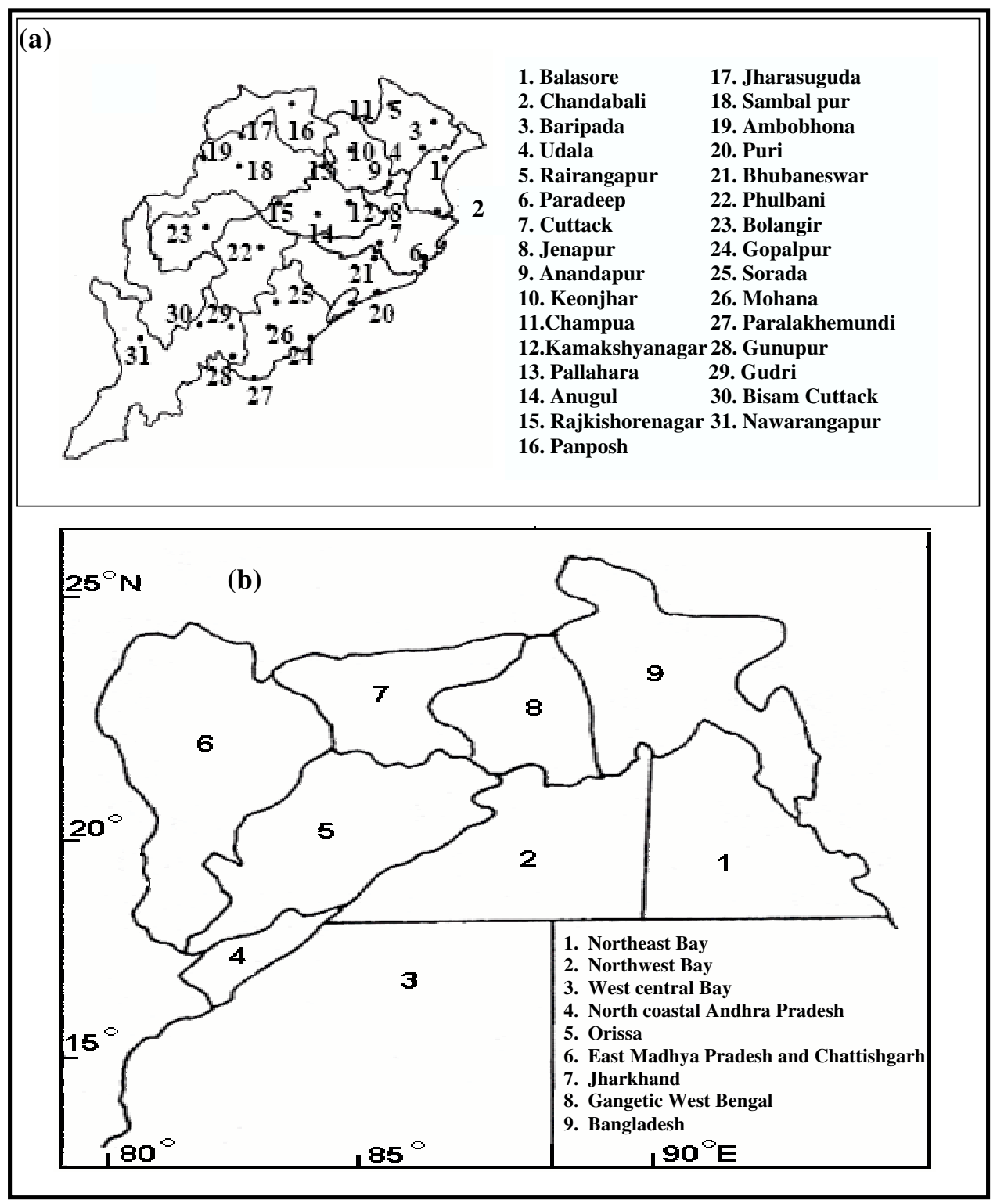

Figure 2. (a) Selected rain gauge stations in Orissa and (b) regions of occurrence of LPS under consideration.

over Orissa. A day is considered as a depression/ cyclonic storm day over a region if the centre of LPS is detected over that region according to 0300UTC synoptic observation of that day. The centre of the low is not well defined. A day is considered as a low day over a region if the major part of the low lies over that region according to 0300UTC synoptic observation of that day. Though recently, east Madhya Pradesh and Chattishgarh are made two separate meteorological sub-divisions of India, it has been considered as single subdivision in this study, which is the same as the old meteorological sub-division of east Madhya Pradesh.

Different statistical characteristics like mean and coefficients of variation (CV) of rainfall and rainy days over different stations under consideration in Orissa are calculated for different monsoon months and for the season as a whole. The spatial patterns of average rainfall, average number of rainy days, $\mathrm{CV}$ of rainfall and $\mathrm{CV}$ of number of rainy days are prepared and analysed in relation to LPS during different monsoon months and the season as a whole. The mean and CV of both rainfall and number of rainy days are compared with those based on the data of 1901-1950 (IMD 1971) to find out the significant changes, if any, in recent years. The correlation coefficients (CC) of the rainfall and number of rainy days over the selected 31 stations under consideration as shown in figure 2(a) with the number of LPS days over different regions under consideration as shown in figure 2(b) are calculated for different monsoon months and the season as a whole and analysed to find out their 
degree of association. To find out the impact of the absence of LPS over the whole region under consideration (figure $2 \mathrm{~b}$ ) on rainfall and rainy days, the relationship of the number of days without any LPS over the whole region under consideration (LPS-free days) with the rainfall and rainy days over different stations in Orissa during different monsoon months and the season as a whole are also analysed. The CCs of rainfall and number of rainy days with the number of LPS-free days are calculated and significant relations are brought out. The significance of the CC has been tested at 95\% level of confidence. The linear trend coefficients of rainfall and number of rainy days over different stations in Orissa during different monsoon months and season as a whole based on data of 1980-1999 are calculated. The significance of the trend coefficients has been tested at $95 \%$ level of confidence. The spatial patterns of trend coefficients of rainfall and number of rainy days are analysed to find out the recent trends and associated physical processes.

\section{Results and discussion}

The mean and the interannual variation of rainfall and number of rainy days over Orissa during different summer monsoon months and the season as a whole are analysed and discussed in sections 3.1 and 3.2 respectively. The relationship of LPS over different regions under consideration with rainfall and number of rainy days over Orissa during different summer monsoon months and the season as a whole is analysed and discussed in section 3.3. The relationship of LPS-free days with rainfall and number of rainy days over Orissa during different summer monsoon months and the season as a whole is presented in section 3.4. The recent trends in the rainfall and number of rainy days over Orissa during different summer monsoon months and the season as a whole are analysed and discussed in section 3.5.

\subsection{Mean rainfall and rainy days over Orissa}

There is east-west orientation in the region of higher rainfall during all the monsoon months and the season as a whole (figure 3a), being significantly so during August due to the fact that (i) the LPS days are higher over NW Bay (Mohapatra and Mohanty 2004) with the monsoon trough extending west-northwestwards from the centre of the system during all the months being significantly so during August and (ii) relatively higher rainfall occurs to the south of the monsoon trough at sea level (Pathan 1993). During June, both the mean rainfall and number of rainy days are significantly higher over northeast Orissa as the monsoon trough lies in relatively northerly position and the LPS forms and moves over relatively northerly latitude (Mohapatra and Mohanty 2005). The mean rainfall and number of rainy days are higher over the western side of the Eastern Ghats during July and August due to the interaction of orography with the basic westerly monsoon flow and the LPS over NW Bay. Due to the basic westerly flow, the western side of the Eastern Ghats becomes windward side to get more rainfall. There is no such well defined east-west oriented region of maxima in mean number of rainy days except that a region of maxima lies in more northerly position during August and the season as a whole. It may be due to the fact that the rainfall can occur all around the trough leading to rainy days.

Comparing the mean rainfall over Orissa as a whole during 1980-1999 with that during $1901-1950$, there is significantly less rainfall during July (14\% less) and the monsoon season in recent years (table 1). Comparing the spatial patterns (figure 3(a and $\mathrm{c})$ ), the rainfall has been significantly less over most parts of Orissa except the eastern side of Eastern Ghats in July leading to less seasonal rainfall during 1980-1999 than during 1901-1950. It may be due to the fact that there is a decrease in LPS days (table 2) in July over the total regions under consideration, especially over NW Bay. There is no significant difference in rainfall over the eastern side of Eastern Ghats from the normal rainfall during all the monsoon months and the season as a whole. It may be due to the fact that there is an increase in LPS days over WC Bay during 1980-1999 compared to the long period average. According to Jadhav (2002), the mean number of LPS days per year over the grid of $15^{\circ} \mathrm{N}$ to $20^{\circ} \mathrm{N}$ and $80^{\circ} \mathrm{E}$ to $85^{\circ} \mathrm{E}$ which covers most parts of WC Bay, NCAP and adjoining southern parts of EMPC and Orissa are 0.14, 0.19, 0.27, 0.85 and 1.45 during $1891-1990$ against $0.45,0.20,0.5,0.65$ and 1.8 together over WC Bay and NCAP during 1980-1999 in June, July, August, September and the season as a whole respectively. The LPS over WC Bay yields good rainfall over the eastern side of Eastern Ghats as it becomes windward side due to basic easterly wind prevailing over the region in association with the LPS. There is no significant difference in the number of rainy days over Orissa as a whole during 1980-1999 from the long period average during different monsoon months and the season except July when it is slightly less (table 1). It may be due to the fact that while the rainfall in July depends significantly on the monsoon disturbances, the number of rainy days depends on the activity of the monsoon trough. To verify this fact, the days of all India break (weak) monsoon conditions during July and August over 


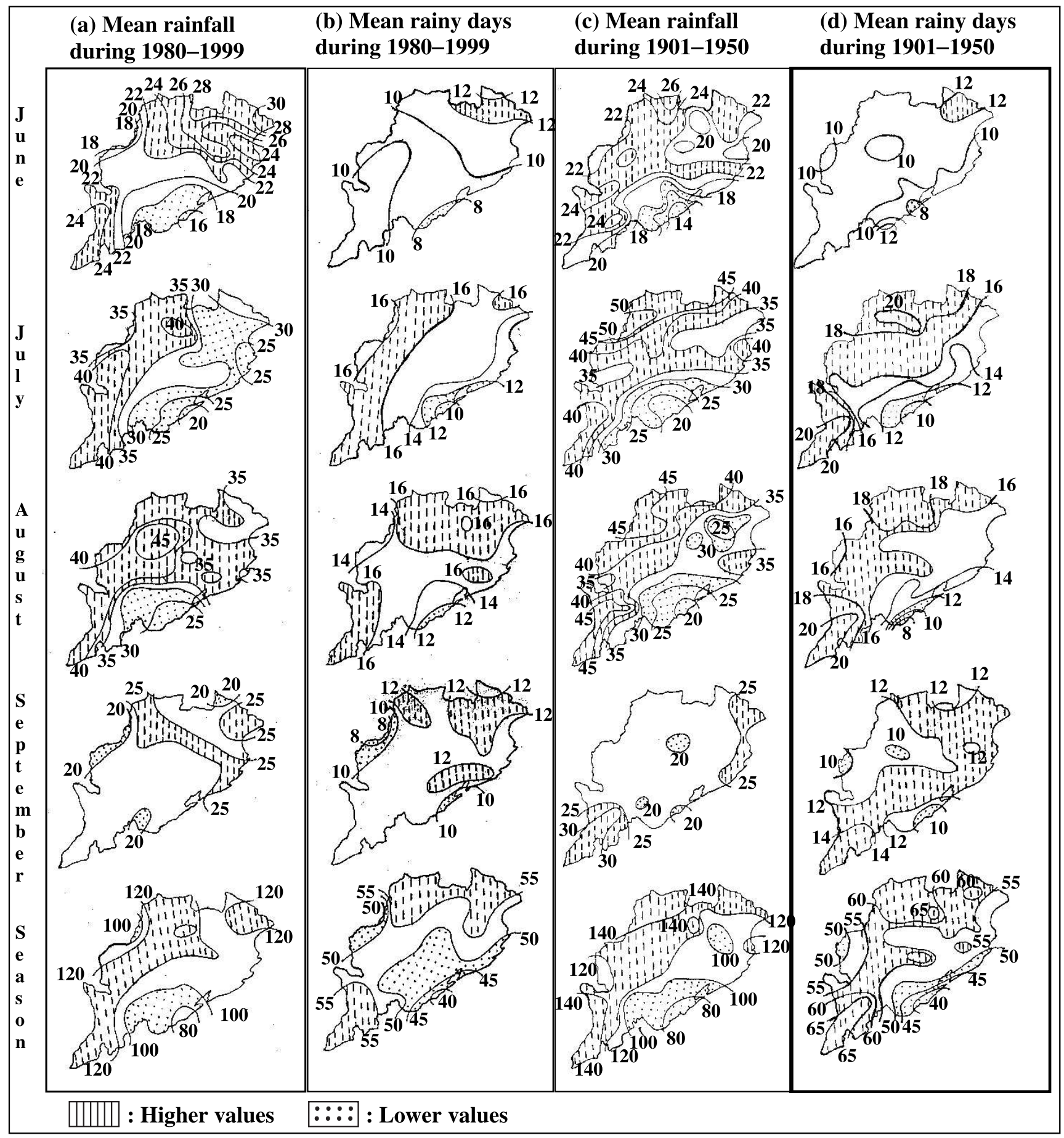

Figure 3. The mean rainfall (in cm) and rainy days over Orissa based on data of 1980-1999 and 1901-1950. (a) Mean rainfall over Orissa during 1980-1999, (b) mean number of rainy days during 1980-1999, (c) mean rainfall over Orissa during 1901-1950 and (d) mean number of rainy days during 1901-1950.

the period of 1980-1999 are found out based on the criteria of Ramamurthy (1969). The criteria of break monsoon condition include the location of monsoon trough along/close to the foothills of the Himalayas. There is significantly less number of days of break monsoon condition in July during 1980-1999 compared with those based on long period data (table 3). Considering the LPS-free days, there is an increase in the number of LPSfree days during July (table 4).

\subsection{Interannual variability of rainfall and rainy days over Orissa}

The CV of both monsoon rainfall and number of rainy days over Orissa as a whole during the period 
Table 1. Mean rainfall ( $\mathrm{cm}$ ) and mean number of rainy days over Orissa during monsoon season.

\begin{tabular}{lcclccc}
\hline Parameter & Period & June & July & August & September & Season \\
\hline Rainfall & $1980-1999$ & 22.8 & 30.6 & 35 & 23.3 & 111.7 \\
Rainfall & $1901-1950$ & 21.1 & 35.7 & 34.7 & 23.4 & 115.8 \\
Rainy day & $1980-1999$ & 10.5 & 14.8 & 15.7 & 1.7 & 12 \\
Rainy day & $1901-1950$ & 10 & 16 & 16 & 54 \\
\hline
\end{tabular}

Table 2. Mean and coefficients of variation (CV) of LPS days over total regions under consideration.

\begin{tabular}{lcccccc}
\hline Parameter & Period & June & July & August & September & Season \\
\hline Mean & $1980-1999$ & 8.7 & 7.9 & 14.2 & 10.5 & 41.3 \\
Mean & $1891-1990$ & 6.9 & 9.0 & 11.2 & 36.4 \\
CV (\%) & $1980-1999$ & 65 & 47 & 36 & 51 & 28 \\
\hline
\end{tabular}

The values during 1891-1990 are approximated from grid point values calculated by Jadhav (2002).

Table 3. Mean and coefficients of variation (CV) of all India break monsoon days.

\begin{tabular}{lccc}
\hline Parameter & Period & July & August \\
\hline Mean & $1980-1999$ & $\mathbf{2 . 7}$ & 1.6 \\
Mean & $1888-1999$ & 3.7 & 3.8 \\
CV (\%) & $1980-1999$ & 116 & 141 \\
CV (\%) & $1888-1999$ & 116 & 116 \\
\hline
\end{tabular}

The mean value during 1980-1999, which is significantly less than that during 1888-1999 at 95\% level of confidence is shown in bold figure.

under study (table 5) is more during June and September. It may be due to the fact that the onset and withdrawal of monsoon over India normally occur during June and September respectively. The monsoon trough is not well defined during these months and also there is a large scale interannual variation in the dates of onset and withdrawal of monsoon over different parts of India. The interannual variation of both rainfall and number of rainy days is more over south coastal Orissa than over north coastal Orissa during all the monsoon months and the season as a whole (figure 4) as south coastal Orissa gets good rainfall due to the LPS over WC Bay and the LPS days over WC Bay show high interannual variation. The region extending from central part of coastal Orissa to western Orissa experiences higher interannual variation of rainfall during July and August as the rainfall over this region is significantly dependent on the number of LPS developing and persisting over NW Bay with the monsoon trough extending west-northwestwards from the centre of the system. The number of LPS days over NW Bay shows high interannual variability (Mohapatra and Mohanty 2004). Compared to the climatology (IMD 2002), the spatial pattern of CV of seasonal rainfall during 1980-1999 does not show any significant departure from the normal pattern. However, the seasonal rainfall shows higher interannual variation (increase in CV by about $5 \%$ ) during 1980-1999 than during 1901-1990 over most parts of Orissa except northeast Orissa. Comparing the spatial pattern of rainy days during 1980-1999 with the climatological pattern (IMD 2002), there is no significant difference in interannual variation of rainy days over different parts of Orissa and Orissa as a whole over the years.

\subsection{Rainfall and rainy days over Orissa in relation to LPS}

The relationship of rainfall and number of rainy days over different stations in Orissa (figure 2a) with the number of LPS days is analysed with respect to the location of LPS over different regions under consideration as shown in figure 2(b) by calculating the correlation coefficients (CC) between them. The results of the analysis along with the discussions are presented in section 3.3.a to section 3.3.d.

\section{3.a Rainfall and rainy days over Orissa in relation to LPS over WC Bay and EMPC}

From figure $5(\mathrm{a}-\mathrm{b})$, both the rainfall and number of rainy days over northeast Orissa significantly decrease with increase in number of LPS days over WC Bay during June as this region lies in the outer periphery of the right rear sector (sector of minimum convergence and vertical motion) of this LPS. Also in June, the monsoon trough lies normally over the northern latitude passing through GWB. Hence, there is significant deviation in the flow pattern in association with the LPS over WC Bay from the normal pattern during June. The rainfall and number of rainy days during the season as a whole over some parts of western Orissa 
Table 4. Mean and coefficients of variation (CV) of LPS free days over Orissa and adjoining land and sea regions under consideration.

\begin{tabular}{lllllcc}
\hline Parameter & Period & June & July & August & September & Season \\
\hline Mean & $1980-1999$ & 20.9 & $\mathbf{2 2 . 5}$ & 16.3 & $\mathbf{1 9 . 1}$ & $\mathbf{7 8 . 8}$ \\
Mean & $1891-1990$ & 19.3 & 17.1 & 14 & 25 & 14.5 \\
CV $(\%)$ & $1980-1999$ & 29 & 17 & 35 & 25 \\
\hline
\end{tabular}

The mean values during 1980-1999, which is significantly higher than that during 1891-1990 (after Jadhav 2002) are shown in bold figure.

Table 5. Coefficients of variation (\%) of rainfall and number of rainy days over Orissa during monsoon season.

\begin{tabular}{lcccccc}
\hline Parameter & Period & June & July & August & September & Season \\
\hline Rainfall & $1980-1999$ & 29 & 21 & 25 & 29 & 13 \\
Rainy day & $1980-1999$ & 21 & 13 & 14 & 22 & 09 \\
\hline
\end{tabular}

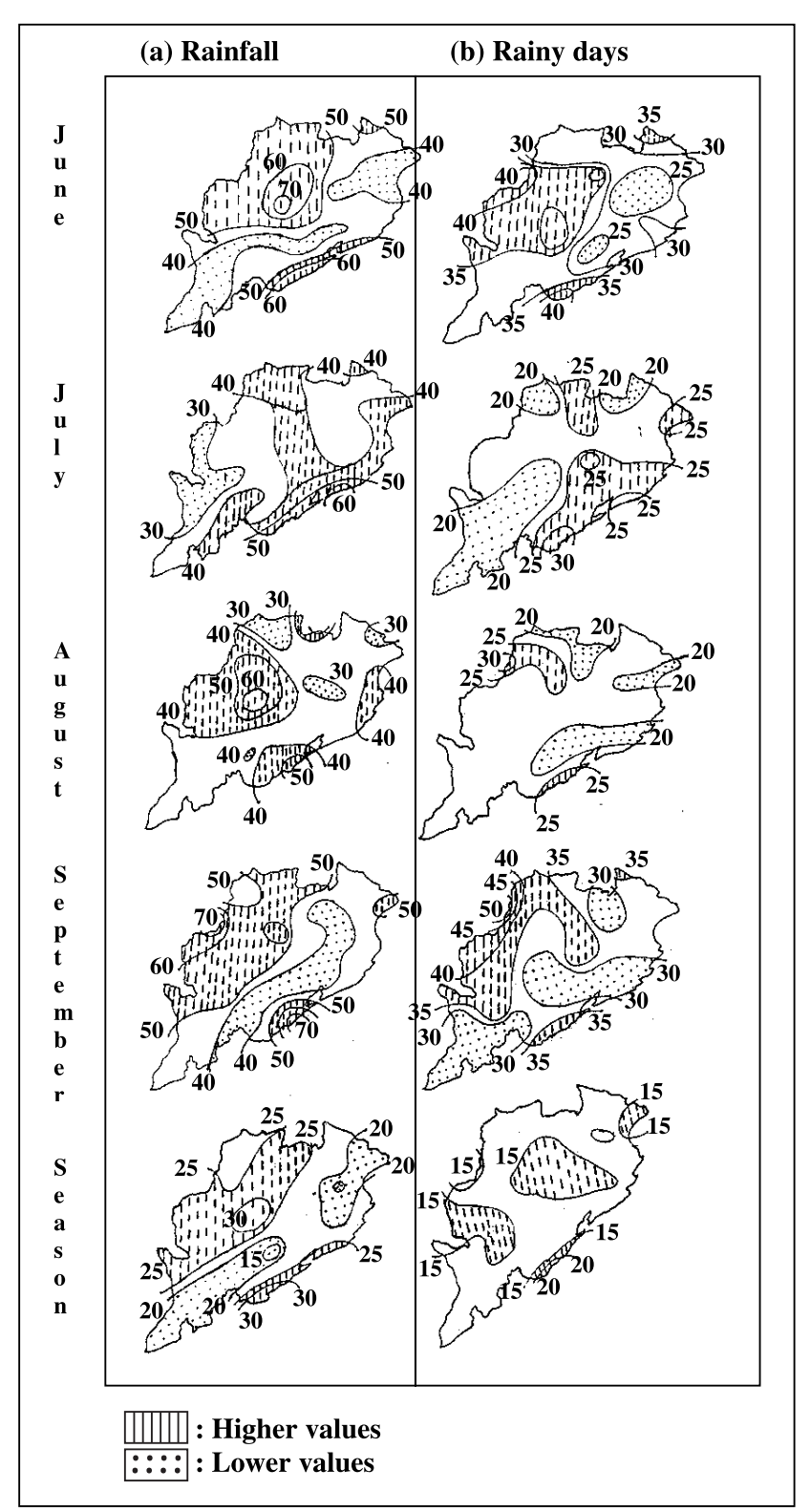

Figure 4. Coefficients of variation (CV in \%) of (a) rainfall and (b) number of rainy days over Orissa during summer monsoon season. including the western side of Eastern Ghats significantly decrease with increase in LPS days over WC Bay. As with the LPS over WC Bay, the basic flow over most parts of Orissa becomes easterly in lower tropospheric levels, the western part of Orissa lies on the lee side of Eastern Ghats and gets less rainfall. As the central part of coastal Orissa generally gets good rainfall due to basic westerly flow in association with the LPS over NW Bay, its rainfall and number of rainy days significantly decrease with the increase in LPS days over WC Bay during August, the month of maximum number of LPS days over NW Bay. The rainfall and number of rainy days over extreme southern part of Orissa, especially the eastern side of Eastern Ghats increase significantly with the increase in LPS days over WC Bay during August and September as it lies in the vicinity of the system as well as in the windward side of Eastern Ghat.

The rainfall increases over some parts of coastal Orissa and adjoining areas on the eastern side of Eastern Ghats with increase in LPS days over EMPC during July (figure 5). The seasonal rainfall and rainy days significantly decrease over some isolated parts of Eastern Ghat region, as it lies on the rear sector of the LPS over EMPC.

\section{3.b Rainfall and rainy days over Orissa in relation to LPS over $N W$ Bay and Orissa}

From figure $6(\mathrm{a}-\mathrm{b})$, both the rainfall and rainy days during the season as a whole significantly increase over most parts of Orissa with the increase in number of LPS days over NW Bay, unlike the monthly rainfall and rainy days, which significantly increase over a limited area of the state. The rainfall significantly increases over the region extending from the central part of coastal Orissa to western Orissa during different monsoon months and the season with increase in number of LPS days over NW Bay. It may be due to the fact that with the LPS 




Figure 5. Correlation coefficients (CC) of rainfall and rainy days over Orissa with number of LPS days over WC Bay and EMPC during summer monsoon season. (a) CC between rainfall over different stations in Orissa and number of LPS days over WC Bay, (b) CC between number of rainy days over different stations in Orissa and number of LPS days over WC Bay, (c) CC between rainfall over different stations in Orissa and number of LPS days over EMPC and (d) CC between number of rainy days over different stations in Orissa and number of LPS days over EMPC.

over NW Bay, the monsoon trough generally runs to northwest India across north Orissa and the region a little to the south of the monsoon trough gets maximum rainfall (Pathan 1993 and Saha and Saha 1981). The east-west orientation in CC of rainfall and rainy days with LPS days over NW Bay is most distinctly observed during August as the number of LPS days over NW Bay is maximum during August (Mohapatra and Mohanty 2004).

From figure $6(\mathrm{c}-\mathrm{d})$, with increase in LPS days over Orissa, the rainfall significantly increases over south Orissa during June, over interior Orissa during July and over the central zone during August. The seasonal rainfall significantly increases over many parts of Orissa, especially western Orissa with increase in LPS days over Orissa, as western Orissa lies in the southwest sector of this LPS with the monsoon trough extending from the centre of the LPS to northwest India and NW Bay. The significant CCs of LPS days with both rainfall and rainy days show east-west orientation during June, July, August and season as a whole due to 


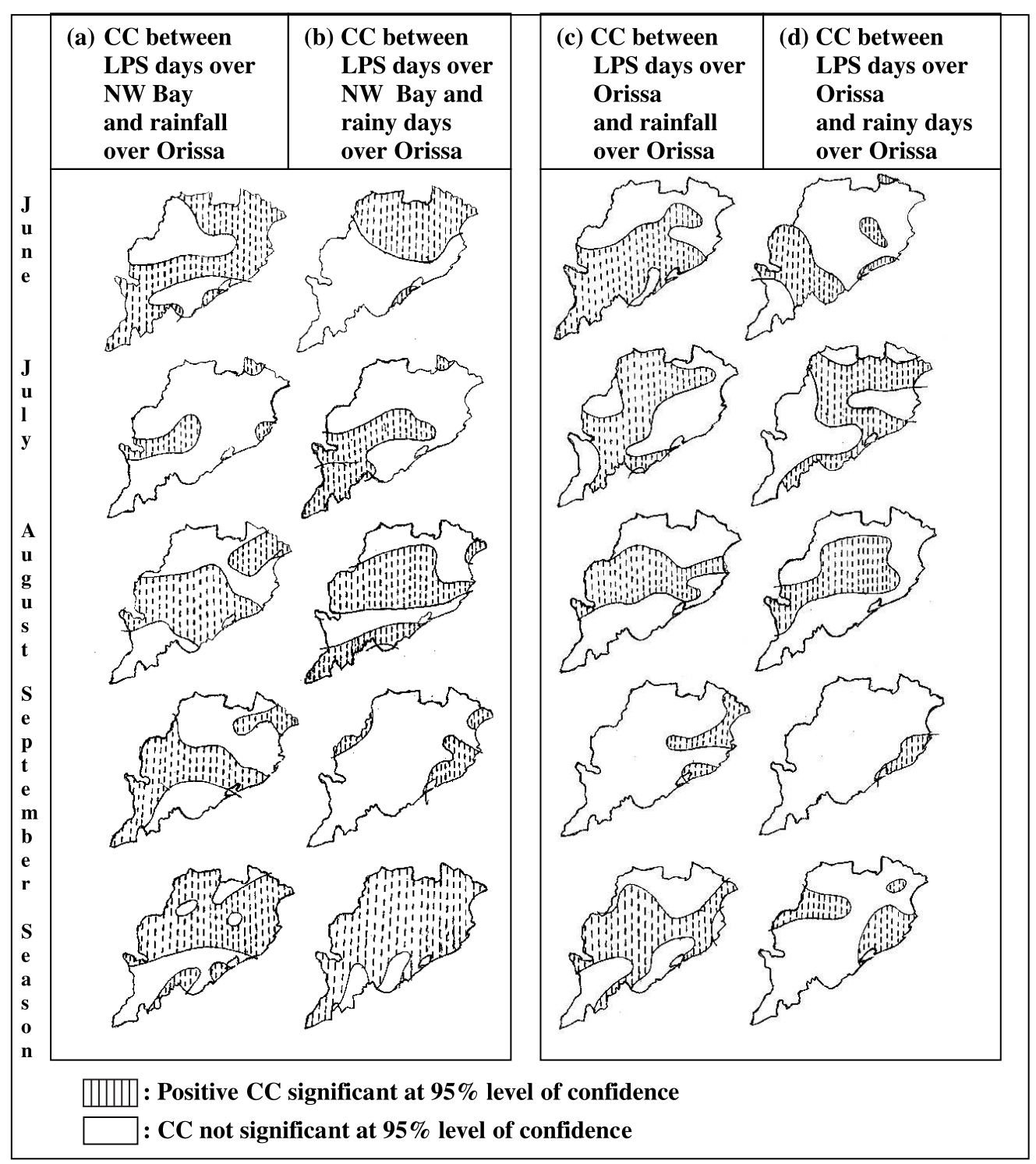

Figure 6. Correlation coefficients (CC) of rainfall and rainy days over Orissa with number of LPS days over NW Bay and Orissa during summer monsoon season. (a) CC between rainfall over different stations in Orissa and number of LPS days over NW Bay, (b) CC between number of rainy days over different stations in Orissa and number of LPS days over NW Bay, (c) CC between rainfall over different stations in Orissa and number of LPS days over Orissa and (d) CC between number of rainy days over different stations in Orissa and number of LPS days over Orissa.

east-west orientation of the monsoon trough and maximum rainfall zone to the south of the monsoon trough in association with the LPS over Orissa. However, this orientation is more marked in case of rainfall.

\section{3.c Rainfall and rainy days over Orissa in relation to LPS over $G W B$ and JKD}

The LPS over GWB has significant impact on rainfall and number of rainy days only during June (figure 7). Many parts of north Orissa and western side of Eastern Ghats experience increase in rainfall and number of rainy days due to the increase in number of LPS days over GWB during June. The relatively smaller part of north Orissa and western side of Eastern Ghats also experience significant increase in rainfall during July due to increase in LPS days over GWB. It may be due to higher number of LPS days over GWB during June followed by July (Mohapatra and Mohanty 2004). Normally the monsoon trough passes through GWB and JKD during June. With the increase in LPS days over GWB, both the rainfall and number of rainy days significantly decrease over some parts on the eastern side of Eastern Ghats during the season as a whole, as this region lies on the lee side with basic monsoon flow becoming westerly over the region with this LPS. 


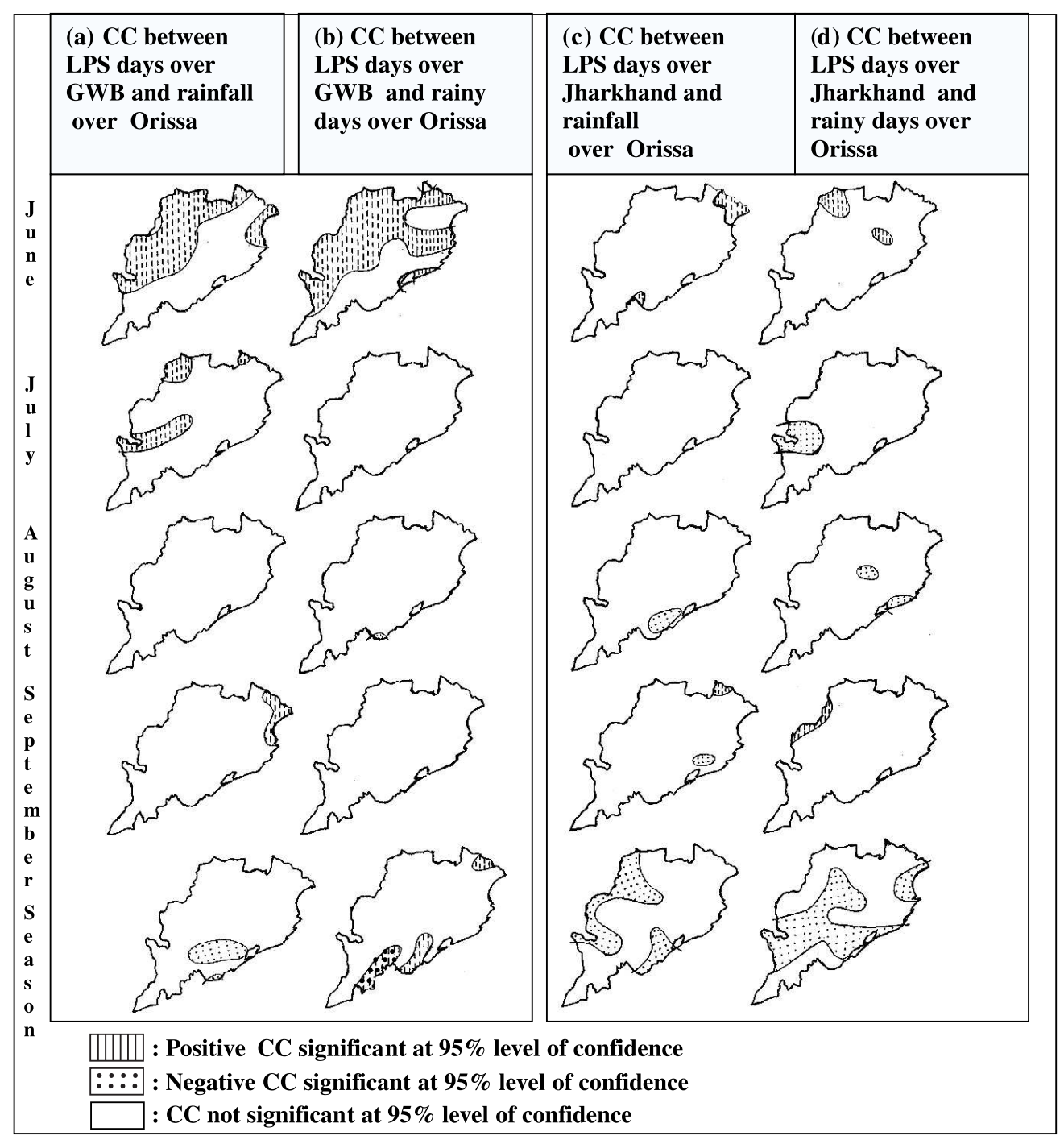

Figure 7. Correlation coefficients (CC) of rainfall and rainy days over Orissa with number of LPS days over GWB and Jharkhand during summer monsoon season. (a) CC between rainfall over different stations in Orissa and number of LPS days over GWB, (b) CC between number of rainy days over different stations in Orissa and number of LPS days over GWB, (c) CC between rainfall over different stations in Orissa and number of LPS days over Jharkhand and (d) CC between number of rainy days over different stations in Orissa and number of LPS days over Jharkhand.

Both the rainfall and rainy days also significantly increase (figure 7) over some parts of north Orissa during June with increase in LPS days over JKD. During the season as a whole, both the rainfall and number of rainy days significantly decrease over some parts of Orissa with increase in number of LPS days over JKD. It may be due to the fact that the monsoon trough and hence the zone of maximum rainfall in association with the LPS over JKD shifts northward. Also, most parts of Orissa do not lie in the southwest sector of LPS over JKD.

\section{3.d Rainfall and rainy days over Orissa} in relation to LPS over NE Bay and Bangladesh

From figure $8(\mathrm{a}-\mathrm{b})$, the rainfall significantly increases over the western side of Eastern Ghats and extreme north Orissa during June with increase in LPS days over NE Bay. Significant decrease in both rainfall and rainy days over many parts of Orissa, especially over central Orissa extending from east to west during September may be due to the fact that the monsoon trough is not well marked during this month and the eastern end of monsoon trough shows wide fluctuations in position and orientation, more often extending to north-northwest direction (Rao 1976). In addition, there is marked deviation in the flow pattern from the normal with the LPS over NE Bay in September, as climatologically the LPS generally forms over relatively southerly latitude in Bay of Bengal during September (Rao 1976; Jadhav 2002). Hence, the southwest sector of the LPS gets comparatively less rainfall in September than in July and August. 


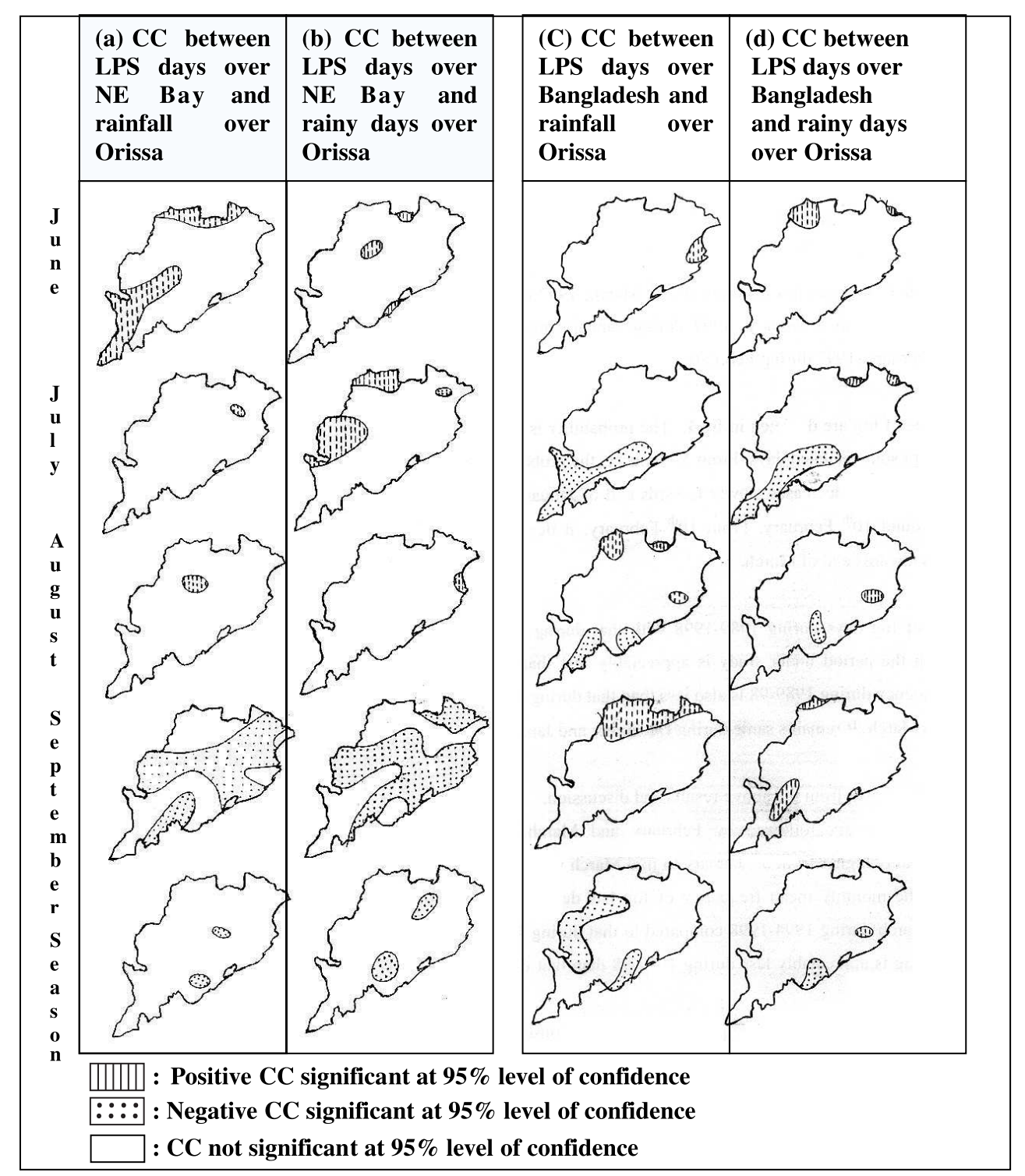

Figure 8. Correlation coefficients (CC) of rainfall and rainy days over Orissa with number of LPS days over NE Bay and Bangladesh during summer monsoon season. (a) CC between rainfall over different stations in Orissa and number of LPS days over NE Bay, (b) CC between number of rainy days over different stations in Orissa and number of LPS days over NE Bay, (c) CC between rainfall over different stations in Orissa and number of LPS days over Bangladesh and (d) CC between number of rainy days over different stations in Orissa and number of LPS days over Bangladesh.

From figure $8(\mathrm{c}-\mathrm{d})$, only some isolated parts of north Orissa experience significant increase in rainfall due to the increase in number of LPS days over Bangladesh during individual monsoon months as the LPS lies to the north away from Orissa. Some parts of south Orissa, especially the Eastern Ghat region get less rainfall and number of rainy days during July, August and season as a whole due to increase in LPS days over Bangladesh. As the monsoon trough shifts northward in association with the LPS over Bangladesh, the zone of maximum rainfall also shifts northward. Due to the northward location of LPS, the strength of westerly wind over the Eastern Ghat region of Orissa decreases. Hence, the interaction of basic westerly monsoon flow with the orography due to the Eastern Ghats also decreases with LPS over Bangladesh.

Comparing the spatial patterns of $\mathrm{CC}$ of rainfall and rainy days with LPS days over different regions (figures 5-8), there are significant spatial and temporal variations of rainfall and rainy days over Orissa in relation to LPS. Most parts of Orissa, especially the region extending from central part of coastal Orissa to western Orissa (central zone) and western side of the Eastern Ghats get more seasonal monsoon rainfall with the development and persistence of LPS over NW Bay and their subsequent movement and persistence over Orissa. The north Orissa adjoining the central zone also gets 
more seasonal rainfall with more development and persistence of LPS over NW Bay. While the seasonal rainfall over the western side of the Eastern Ghats is adversely affected due to increase in LPS days over WC Bay, JKD and Bangladesh, that over the eastern side of the Eastern Ghats is adversely affected due to increase in LPS days over all the regions to the north of Orissa. The large spatiotemporal variation in the impact of the LPS on rainfall and rainy days may be due to the fact that the deficient/excess rainfall over different parts of Orissa can be due to local as well as remote forcing apart from the impact of the LPS. For example, the local forcing may include antecedent land surface condition. The length of time for retention of soil moisture over different soil structure of Orissa is important. Freak early season rain even from pre-monsoon thunderstorm can wet the soil and wetness retain for the period of the order of a couple of weeks. They can contribute to new convective cells through enhanced buoyancy and convectively available potential energy, which in turn can invite meso-scale moisture convergence and new rains from remote areas.

\subsection{Rainfall and rainy days in relation to LPS-free days}

Both the rainfall and number of rainy days decrease over most parts of Orissa and Orissa as whole with increase in number of LPS-free days (figure 9). However, the decrease is more significant during June and August. The absence of LPS over the regions under consideration influences the rainfall adversely in two ways: (i) rainfall associated with the LPS is missed and (ii) the rainfall associated with the monsoon trough is reduced, since in the absence of LPS over the regions under consideration, the location and normal activity of the monsoon trough are not maintained. Both the rainfall and number of rainy days are more significantly and adversely affected over some parts of northeast Orissa during the season as a whole. It may be due to the fact that the rainfall over northeast Orissa is more significantly dependent on the LPS and associated monsoon trough in normal position than other regions of Orissa. The western side of Eastern Ghats experiences significant adverse impact on its rainfall due to increase in number of LPS-free days during individual monsoon months, especially during June and August. It endorses the fact that the rainfall over the western side of Eastern Ghats is more dependent on LPS, while the number of rainy days over the region depends on other small scale systems in addition to the LPS. The small scale systems like low level cyclonic circulation over NW Bay and Orissa can interact with basic westerly monsoon flow and orography due to the Eastern Ghats to cause rainfall on the western side of the Eastern Ghats.

\subsection{Recent trends}

The monsoon rainfall and number of rainy days over Orissa as a whole during 1980-1999 show insignificant trends during all the months and the season as a whole (table 6). Considering the spatial distributions of linear trend coefficients of rainfall and rainy days during 1980-1999 (figure 10), there is no significant trend in rainfall and rainy days over most parts of Orissa during all the months and the season as a whole. It may be due to insignificant trends in those LPS days, which are significantly correlated with rainfall and rainy days over Orissa. There is no significant trend in the number of LPS days over different regions under consideration during all the months and the season as a whole based on data of 1980-1999 except that the number of LPS days over GWB shows a significant increasing trend in July and that over NE Bay shows a significant decreasing trend in August (Mohapatra and Mohanty 2004). However, there is significant decreasing trend of rainfall ( $5-10 \mathrm{~mm}$ per year) and rainy days ( 0.2 per year) over extreme southwest Orissa during June (figure 10). Unlike the rainfall, there is significant decreasing trend in number of rainy days (0.2-0.4 per year) over central part of coastal Orissa and some parts of north interior Orissa during July.

\section{Conclusions}

The following broad conclusions are drawn from the above results.

The rainfall has been significantly less than normal over most parts of Orissa except the eastern side of Eastern Ghats during July and hence monsoon season as a whole due to significantly less than normal number of LPS days over NW Bay in July over the period of 1980-1999. The eastern side of Eastern Ghats shows no significant change from the normal rainfall during all the monsoon months and the season as a whole due to increase in LPS days over WC Bay, which is favourable for rainfall over this region.

The seasonal rainfall shows higher interannual variation (increase in CV by about 5\%) during 1980-1999 than during 1901-1990 over most parts of Orissa except northeast Orissa.

There are significant spatial and temporal variations of rainfall and rainy days over Orissa in relation to LPS. Most parts of Orissa, especially the region extending from the central part of coastal Orissa to western Orissa (central zone) and the 


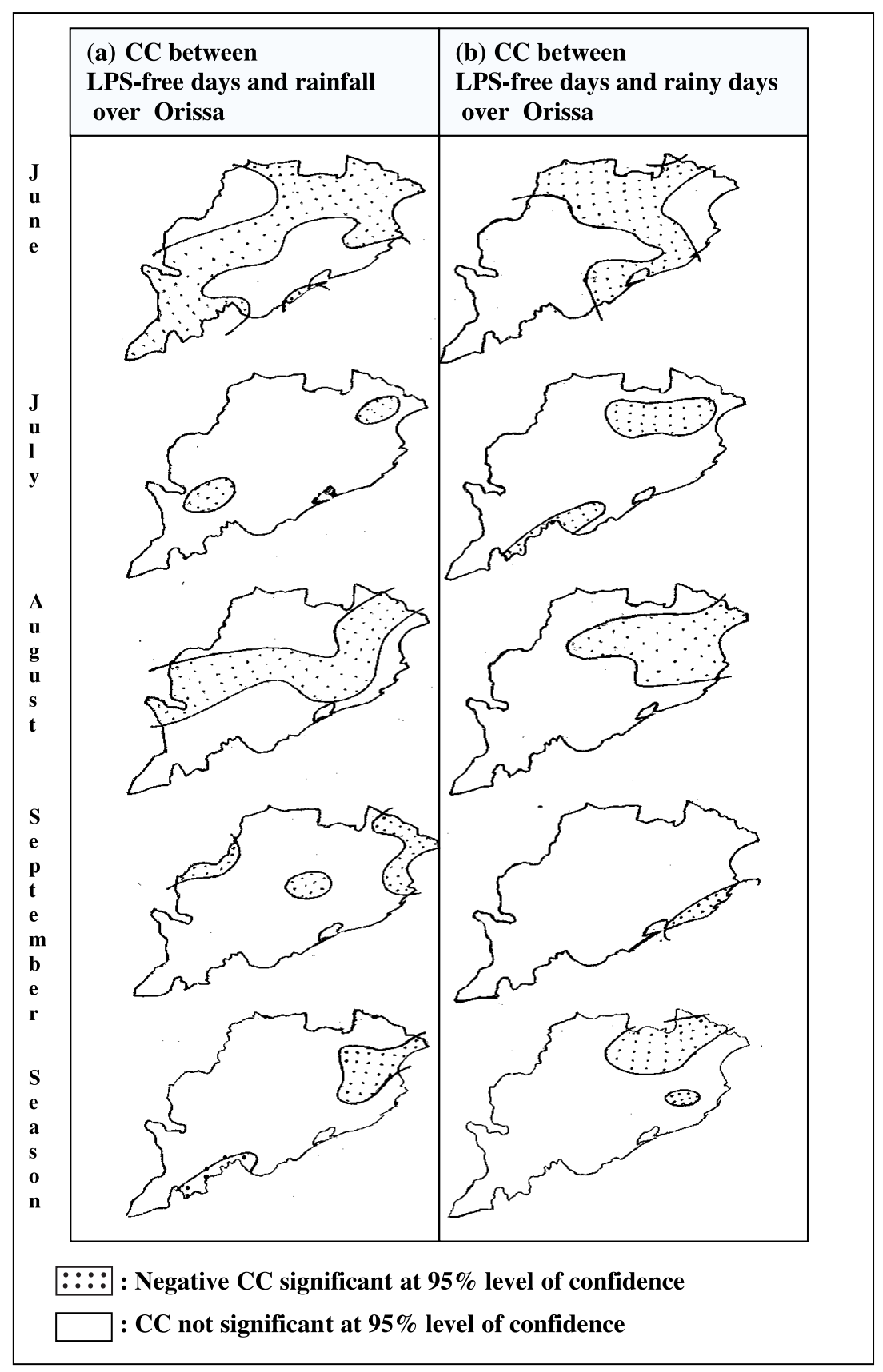

Figure 9. Correlation coefficients (CC) of (a) rainfall and (b) rainy days over different stations in Orissa with number of LPS-free days over region under consideration during summer monsoon season.

Table 6. Linear trend coefficients of rainfall (mm/year) over Orissa, number of rainy days (per year) over Orissa and LPS free days (per year) over Orissa and adjoining land and sea regions during monsoon season based on data of 1980-1999.

\begin{tabular}{lcccrr}
\hline Parameter & June & July & August & September & Season \\
\hline Rainfall & -2.6 & 0.26 & -0.19 & -0.53 & -3.1 \\
Rainy day & -0.08 & -0.07 & -0.00 & 0.02 & -0.14 \\
LPS-free days & 0.24 & -0.21 & 0.30 & 0.17 & 0.49 \\
\hline
\end{tabular}

The linear trend coefficients are not significant at $95 \%$ level of confidence. 


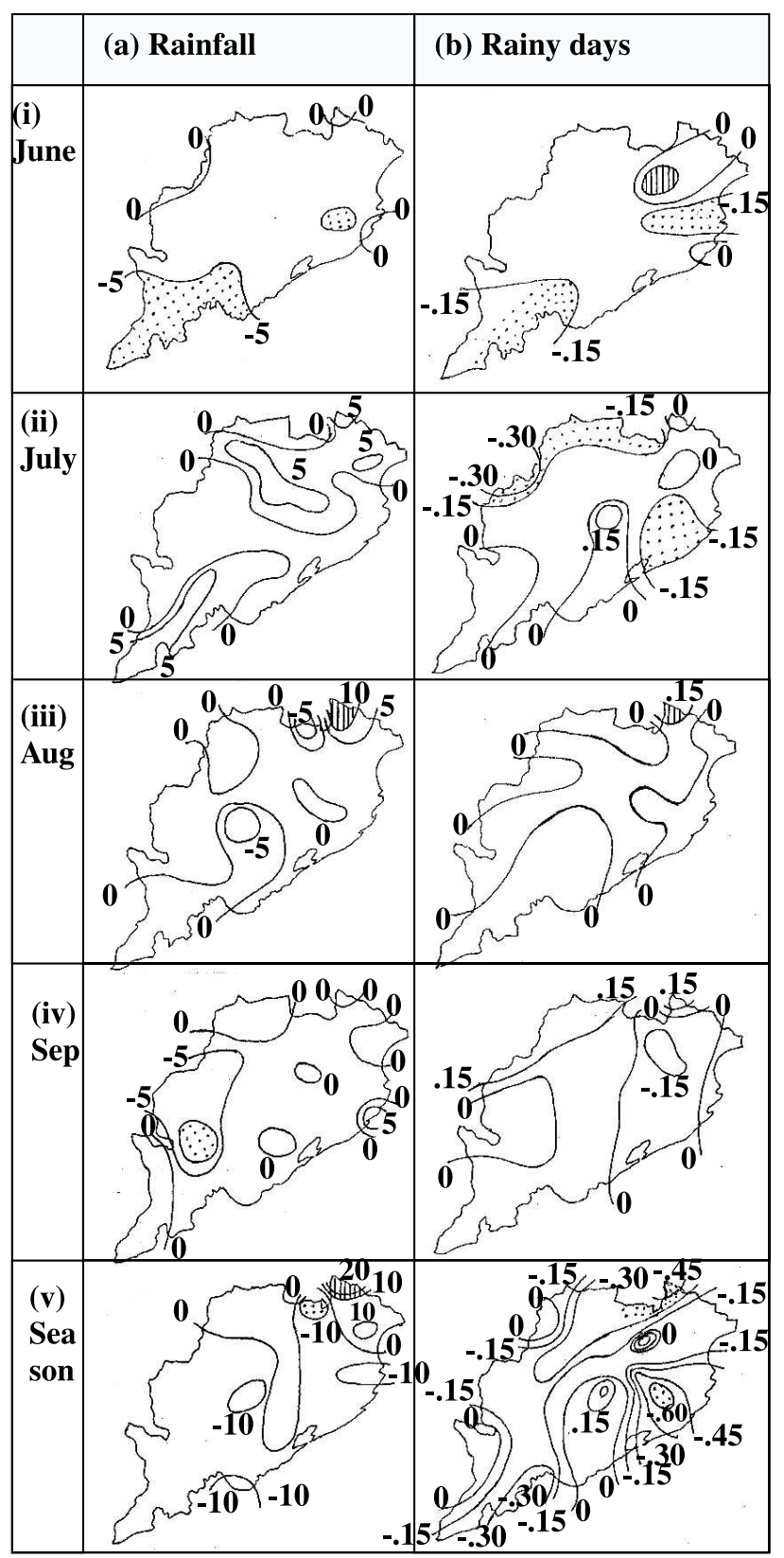

$\mathrm{W} \mathrm{W} \mid \mathrm{l}$ : Positive trend significant at $95 \%$ level of confidence $\therefore:::$ : Negative trend significant at $95 \%$ level of confidence

Figure 10. Linear trend coefficients of (a) rainfall (in $\mathrm{mm}$ per year) and (b) number of rainy days (per year) over different stations in Orissa during summer monsoon season.

western side of the Eastern Ghats get more seasonal monsoon rainfall with the development and persistence of LPS over NW Bay and their subsequent movement and persistence over Orissa. The north Orissa adjoining the central zone also gets more seasonal rainfall with more development and persistence of LPS over NW Bay. While the seasonal rainfall over the western side of the Eastern Ghats is adversely affected due to increase in LPS days over WC Bay, Jharkhand and Bangladesh that over the eastern side of the Eastern Ghats is adversely affected due to increase in LPS days over all the regions to the north of Orissa.

The maps of significant CCs between LPS days over different regions and the rainfall and number of rainy days over Orissa may be useful for short range forecast. The area with significantly positive $\mathrm{CC}$ experiences more rainfall and the area with significantly negative CC experiences less rainfall for a given location of LPS.

The adverse impact of higher number of LPSfree days on the rainfall over Orissa is more in June and August. Both the seasonal rainfall and number of rainy days are more adversely affected over northeast Orissa due to increase in LPS-free days.

During 1980-1999, the seasonal monsoon rainfall and rainy days show insignificant trends over most parts of Orissa due to similar trends in the LPS days, which are significantly correlated with rainfall and number of rainy days. However, there is a significant decreasing trend in rainfall and number of rainy days over some parts of southwest Orissa during June and a decreasing trend in rainy days over some parts of north interior Orissa and the central part of coastal Orissa during July.

\section{Acknowledgements}

The authors are thankful to the India Meteorological Department for providing the data for this work. The first author is thankful to the Director General of Meteorology, IMD for his support and encouragement for this study.

\section{References}

Dhar O N and Mhaiskar P R 1973 Areal and point distribution of rainfall associated with depressions/storms on the day of crossing the east coast of India; Indian J. Met. Geophys. 24 271-278.

Dhar O N, Rackecha P R and Mandal B N 1981 Influence of cyclonic disturbances on monthly monsoon rainfall of India; Mon. Wea. Rev. 109 188-190.

IMD 1971 Monthly and annual rainfall and number of rainy days for the period of 1901-1950; Memoirs of IMD, Vol. XXXI, Part-I.

IMD 2002 Climate of Orissa; Published by Controller of Publications Civil Lines New Delhi, pp. 5.

Jadhav S K 2002 Summer monsoon low pressure systems over the Indian region and their relationship with the sub-divisional rainfall; Mausam 53 177-186.

Joseph P V 1981 Ocean atmosphere interaction on a seasonal scale over north Indian Ocean and Indian monsoon rainfall and cyclonic track - a preliminary study; Mausam 32 237-246.

Mohapatra M and Mohanty U C 2004 Some characteristics of low pressure systems and summer monsoon rainfall over Orissa; Curr. Sci. 87 1245-1255. 
Mohapatra M and Mohanty U C 2005 Some characteristics of very heavy rainfall over Orissa during summer monsoon season; J. Earth Syst. Sci. (Formerly known as Proc. Indian Acad. Sci. (Earth Planet. Sci.)) 114 $17-36$.

Mooley D A 1973 Some aspects of Indian monsoon depression and associated rainfall; Mon. Wea. Rev. 101 $271-280$.

Mooley D A and Shukla J 1989 Main features of the westward moving low pressure systems which form over the Indian region during the summer monsoon season and their relation to the monsoon rainfall; Mausam $\mathbf{4 0}$ $137-152$.

Parthasarathy B, Munot A A and Kothawale D R 1995 Monthly and seasonal rainfall series for all India homogeneous regions and meteorological subdivisions: 1871-1994; Research Report No. RR-065, Indian Institute of Tropical Meteorology, Pune, India.

Pathan J M 1993 Latitudinal variation of rainfall during the month of July in relation to the axis of monsoon trough over India; Mausam 44 384-386.
Pisharoty P R and Asnani G C 1957 Rainfall around monsoon depression over India; Indian J. Met. Geophys. 8 15-20.

Raghavan K 1973 Break monsoon over India; Mon. Wea. Rev. 101 33-44.

Rajamani S and Rao K V 1981 On the occurrence of rainfall over southwest sector of monsoon depression; Mausam 32 215-220.

Ramamurthy K 1969 Some aspects of break in the Indian southwest monsoon during July and August; India Met. Dept. FMU Rep.-IV-18.3.

Rao Y P 1976 Southwest monsoon; India Met. Dept. Met. Monogr. Syno. Met. No. 1/1976, pp. 1-367.

Saha N C and Saha S 1981 The vertical slope of monsoon trough and its association with distribution of rainfall over India; Mausam 32 79-84.

Sikka D R 1980 Some aspects of the large scale fluctuation of summer monsoon rainfall over India in relation to fluctuation in the planetary and regional scale circulation parameters; Proc. Indian Acad. Sci. (Earth Planet. Sci.) 89 179-195. 